\title{
Investigating the Effect of Music on Behavior of Apparel Consumers
}

\author{
Soheil Sarmad Saeedi ${ }^{1}$, Ali Abbasi Raei ${ }^{2}$, Javad Faghihi Pour ${ }^{3 *}$, Mohammad Mehdi ${ }^{4}$ \\ ${ }^{1}$ Department of Management, Islamic Azad University, Tehran Central Campus, Tehran, Iran; ${ }^{2}$ Industrial Engineering, The Univer- \\ sity of Tarbiat Modarress, Tehran, Iran; ${ }^{3}$ Marketing Management, Department of Management, Islamic Azad University, Tehran \\ Central Campus, Tehran, Iran; ${ }^{4}$ Financial Management, School of Economic Sciences University, Tehran, Iran. \\ Email: ${ }^{*}$ ja_faghihi@yahoo.com, ${ }^{*}$ hasan_hosseini96@yahoo.com
}

Received December $22^{\text {nd }}, 2012$; revised February $20^{\text {th }}, 2013$; accepted March $24^{\text {th }}, 2013$

Copyright (C) 2013 Soheil Sarmad Saeedi et al. This is an open access article distributed under the Creative Commons Attribution License, which permits unrestricted use, distribution, and reproduction in any medium, provided the original work is properly cited.

\begin{abstract}
Companies aim to win customers loyalty by establishing long-term relationship with them. Relationship Marketing techniques as the marketing execution arms secure the existing customer retention and meet customers' needs and win their trust through a high quality relationship which eventually leads to their loyalty. Loyal customers, despite environmental factors and advertisement of competitors, tend to repurchase from the firm and guarantee its profitability in today's turbulent market. This research, following review of the prior research and collecting information from reliable sources, investigates the relationship of music on behavior of apparel consumers in the city of Tehran. In fact, present research seeks to answer the question as whether music exercises any influence in behavior of apparel consumers. The required data were gathered based on the research theoretical framework and through the distribution of 450 questionnaires among apparel buyers and consumers over city of Tehran. From 450 distributed questionnaires, 434 were appropriately filled and used for analysis. Using multivariate linear regression test the research hypotheses were examined. The results indicated that music broadcasting had no significant effect on the amount of time spent for search in attire store by the buyers, and an inverse correlation was found between music playing and the variable tendency repurchase and to recommend the store to others. The results of the regression tables report an adjusted R2 of 0.013 , indicating the sum of independent variables explains only $1.3 \%$ of the total variance of the dependent variable and the rest of the variance is explained by other factors.
\end{abstract}

Keywords: Music; Consumer's Behavior; Tendency to Repurchase; Tendency to Recommend to Others

\section{Introduction}

Customer retention has attracted considerable attention in recent years, partly because it serves as a means of gaining competitive advantage. When a customer is satisfied, he or she is more likely to shop there again. Satisfaction is believed to influence attitude change and purchase intention [1]. Customers are the driving force of profitability growth and customer loyalty, since customer loyalty can result in profitability [2]. For a customer, loyalty is a positive tendency and behavior expressed in a brand purchase repetition in future [3]. The majority of researchers in the field of marketing share the view suggesting that performance mental criteria such as customer satisfaction and loyalty play a crucial role in performance objective criteria such as profit margin and return on investment (ROI). Therefore, sellers should retain the loyal custom-

\footnotetext{
"Corresponding author.
}

ers who contribute to enterprises' long term profit [4]. The effort to make customers enhance a good relationship with an organization is a way of promoting a firm's financial growth [2]. Apart from this, organizations' financial growth depends on the firm's ability in retaining the existing customers at a higher rate in comparison to finding new customers. Hence, competent managers should realize that growth depends on both attraction of new customers and retention of the existing customers, since the existing customers can be encouraged for more cooperation in advising others to use the firm's services [5]. Considering the intense competition on the market, marketers try to create loyalty in their customers through a variety of marketing activities such as sale, phone contact, electronic purchase, advertisement via TV, Internet, etc, since the evidence indicates when customers' satisfaction is not secured, they will turn to rivals. When the 
market competitive environment becomes turbulent, the most important issue for a seller is not provision of good quality products and services but retention of the existing customers [4]. Retail markets are increasingly becoming more competitive and retailers are continuously looking for differentiation in retail outlets. To compete in such turbulent environment, marketing managers have to draw the firm's strategies beyond the traditional perspective (4Ps strategies) in order to enable the firm to achieve a sustainable competitive advantage. One way to create differentiation is providing a pleasant and exciting purchase environment. The results of studies in this regard provide valuable information for retailers in developing a unique strategy in the store environment which increases purchase experience and results in buyers' greater satisfaction. Since in the today competitive environment, customers' satisfaction is the key factor of competitive advantage for organizations and the perquisite to win their satisfaction is fulfillment of their needs to the full and accurate identification of their wishes, expectation, dispositions, capabilities and limitations in purchase of products. To obtain information on these aspects, determinants of consumers' behavior need to be properly identified and used in marketing decision making [6].

\subsection{Research Theoretical Background}

During the last decade of the $20^{\text {th }}$ century, customer retention has been the main focus and issue of marketing strategy, industrial marketing and consumer marketing [4].

In general, numerous factors affect customer's decision making process one of the most important of which are the situational factors, i.e. all the time and space specific factors which are a function of individual's general knowledge on individual characteristics and stimuli and have a special effect on one's current behavior. Consumers do not only react to such stimuli as advertisement notices or products they see in the store, they are at the same time influenced by situational factors. Some of the situational features which affect consumer's behavior include physical features, social environment, time outlook, operation purposes and prerequisite states [7].

In general, physical features refer to specification of physical surrounding. Physical surrounding includes decoration, scents, lighting, air condition and other factors which serve as stimulus. The sum of physical features of a retail environment is known as the store atmosphere. Store atmosphere has effect on customers' image of the store and their judgment on the store quality. Besides, in some researches, it has been demonstrated that store atmosphere can be of influence on buyers' mood and their interest in strolling and inspecting all over the store and eventually on their purchase decision.
According to Milliman (1982, 1986), in marketing, music affects consumer's behavior especially buyer's behavior [8,9]. In view of Kellaris and Kent (1994), music also affects emotional responses. Music has had a significant role in marketing strategy of many retailers $[10$, $11]$.

According to Pine and Gilmore (1998), store environmental factors such as music and sound, light, color and scent helps creation of sensory images [6,12]. Kotler says the theory suggesting that background music can be used to influence consumer's behavior is derived from the atmospherics [13]. The literature on store atmosphere and condition dates back to late 1960s, starting with the researches of Smith and Curnow (1966) and Kotler (1974) believes atmospherics refers to the environmental aspect which stimulates sensory, conceptive and behavioral responses by the consumer [7,14]. In view of Bruner (1990) and Dube and Morin (2001), music is considered as an effective atmospheric tool to stimulate mood and temperament in retail and services environments $[15,16]$.

According to Kotler (1973), in some purchasing situation, atmospheric condition may have a stronger effect than the product itself [17], and in view of Baker et al. (1992), it may have a direct effect on consumer's behavior [18], and according to Darden and Babin (1994) it may even lead to new attitude and image. The conducted researches over the years have provided some empirical evidence on presence of music effects especially in service environments. However, our knowledge of music effects is still limited [13]. In-store music is an environmental factor which influences consumer's feeling and behavior. Numerous studies have investigated its impact on such variables as consumers' dwell-time in the store, amount of purchase or cost, and recommendation behavior. Milliman $(1983,1986)$ argues that background music creates a tranquilizing and pleasant atmosphere [6,9].

Results of the field studies by Smith and Curnow (1966) have indicated that speed of purchase which is also the case in some cost instances is influenced by music volume [14], and in view of Milliman (1982, 1986), supermarket customers have experienced three states of without music, slow tempo music and fast tempo music. Buyers, according to music tempo, moved quicker or slower, and when softer music was played, they bought $38 \%$ more on daily basis. When the consumers were asked about their awareness of the music, no significance difference between the groups suggesting that music acted in their subconscious was observed $[8,9]$. Second study by Milliman (1986) produced similar results. Background music with fast and slow tempo was randomly played for eight successive weeks in a medium grade restaurant in Dallas. Space of music led the customers to spend more time in the restaurant. In the state of slow tempo music, the customers spent 56 minutes on average to finish their meals. Instead, in state of fast 
tempo music, they spent 45 minutes on average to finish their meal [9].

The added time in the restaurant had no significant effect on food sale. Yet, sales of alcoholic drinks significantly increased. In sum, average gross profit for each group was 55.82 and 48.62 in slow and fast tempo music, respectively. Researches of Milliman (1986) indicated that in a condition where slow tempo music is played, customers spent more time for eating compared to the condition where fast tempo music is played $[9,19]$.

Baker (1986) considered three dimensions in regard to store environment, store's physical nature which is defined as the design dimension and includes such factors as size, architecture, arrangement and display. Social dimension concerns the body of people present in the store, i.e. store's sales assistants and staff. Ambient dimension includes all background stimuli which usually refer to the atmosphere [20].

Sweeny and Wyber (2002) developed the Environmental Psychology Model of Mehrabian-Russell in two dimensions of emotional states and cognitive processing as the modifier variable. Their model showed that music influences customers' perception of product and service quality as well as feeling of arousal and pleasure by them. In the past, not much attention has been paid to effect of music, whereas music qualities (slow or fast) exercise an extra effect on service quality and taking pleasure in it [8].

Spengenberg et al. (2006) investigated the effect of environment's odor on consumers' behavior and evaluation in apparel store and demonstrated that from homogeneity and harmony between gender and product accompanied with fragrance and odor a desirable effect will be achieved [21]. In researches of Morrison et al. (2010), the effect of music (high or low volume) on young customers in a real retail environment was investigated. The results indicated that music volume had a significant effect on customers' satisfaction and feelings. In addition, they demonstrated that music had a significant effect on arousal and pleasure of customers [6].

\subsection{Research Purposes}

This research investigates the effect of music on behavior of apparel consumers in city of Tehran. The purpose of this research can be stated as follows:

1) Investigating the effect of music on behavior of apparel consumers in city of Tehran.

2) Prioritization of the favorite music type within the research statistical population.

Considering the introduced variables, the research theoretical model is presented and eventually given the expected objectives and results and based on the conducted studies, the research hypotheses are composed as follows:

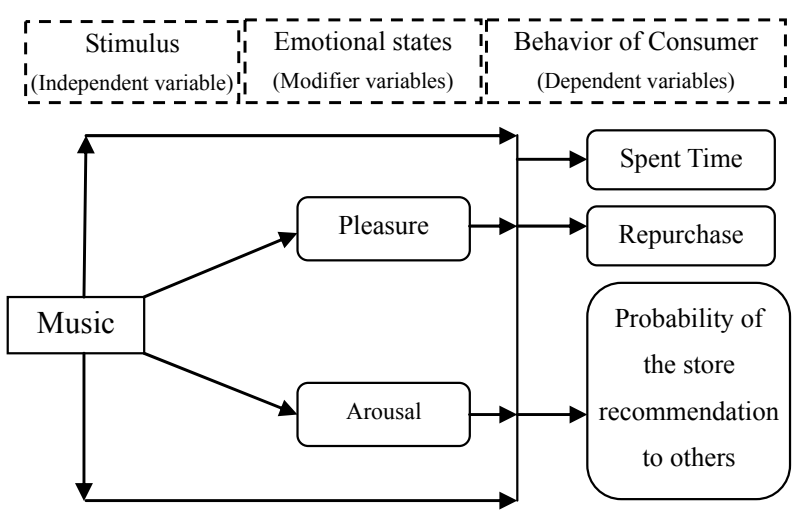

\subsection{Research Conceptual Model}

A. Main hypothesis:

Played music in apparel stores has effect on response and behavior of consumers.

B. Sub-hypotheses:

1) Played music in apparel stores has effect on Consumers' emotional states (pleasure).

2) Played music in apparel stores has effect on Consumers' emotional states (arousal).

3) Played music in apparel stores has effect on spent time for search in the store by consumers.

4) Played music in apparel stores has effect on Consumers' tendency to repurchase.

5) Played music in apparel stores has effect on Consumers' tendency to recommend to others.

6) Consumers' emotional states (arousal) have effect on to spend time for search in the store.

7) Consumers' emotional states (pleasure) have effect on to spend time for search in the store.

8) Consumers' emotional states (arousal) have effect on Consumers' tendency to repurchase.

9) Consumers' emotional states (pleasure) have effect on Consumers' tendency to repurchase.

10)Consumers' emotional state (arousal) Consumers' tendency to recommend to others.

11)Consumers' emotional states (pleasure) have effect on Consumers' tendency to recommend to others.

\section{Method}

Present research, in terms of purpose is of applied type, in terms of data gathering time frame, of survey type, and in terms of data and information collection methods, it is a field study in which a questionnaire in Likert Scale is used. The questionnaire's validity was confirmed by experts and specialists and its reliability using Cronbach Alpha was approved. In addition, for classification of the questions amongst the main factors, factor analysis was employed. The research statistical population includes apparel buyers and consumers within city of Tehran from among of which a sample using random sampling meth- 
od was selected.

\section{Results}

For data analysis, first, a descriptive statistical analysis was performed in which demographical attributes of the research statistical populations were extracted (Table 1).

In Table 2, the type of favorite music of the respondents is shown as frequency and percentage. In general, more than 40 percent of respondents have positively received traditional/classic Iranian music being played in attire stores. The pop music recorded inside the country with 32.2 percent and the pop music recoded outside the

Table 1. Demographical attributes of research statistical population.

\begin{tabular}{cccc}
\hline & Object & Number & Percent \\
\hline \multirow{2}{*}{ Gender } & Male & 179 & 41.3 \\
& Female & 225 & 58.7 \\
Marital state & Married & 194 & 44.7 \\
& Single & 240 & 55.3 \\
state of activity & Employed & 284 & 65 \\
& Unemployed & 150 & 35 \\
\multirow{4}{*}{ Education } & Junior college diploma\& & 226 & 52 \\
& bachelor degree & 178 & 41 \\
& MSc \& higher & 30 & 7 \\
Age & $\leq 30$ & 335 & 77.2 \\
& 30 - 40 & 71 & 16.4 \\
& $\geq 40$ & 28 & 6.4 \\
\hline
\end{tabular}

Table 2. Frequency and percentage of type of favorite music of the respondents.

\begin{tabular}{cccc}
\hline Rows & Styles music & Number & Percent \\
\hline 1 & Music of other nations & 23 & 5.1 \\
2 & religious music & 24 & 5.3 \\
3 & Iranian folkloric music & 55 & 12.2 \\
4 & Western pop music & 55 & 12.2 \\
5 & other cases & 55 & 12.2 \\
6 & Western classic music & 68 & 15.1 \\
7 & Iranian pop music recoded abroad & 103 & 22.9 \\
8 & Iranian pop music recorded inside the & 145 & 32.2 \\
9 & traditional/classic Iranian music & 183 & 40.7 \\
\hline
\end{tabular}

country with 22.9 percent have been the next most favorite music, respectively. It is noteworthy that the respondents were allowed to have more than one option in choice of their favorite music.

Table 2 presents the results of favorite music analysis. This table indicted the tendency of customer to type of music in atmosphere and website although music does not reinforce the tendency to repurchase and the tendency to recommend to others.

To test the research hypotheses and to measure correlation between variables, given the interval scale, Pearson Linear Correlation Test was used (Table 3).

The obtained results from simple linear regression of the independent variables and the dependent variable using Enter Method are provided in the tables below. In Table 4, values of multiple $\mathrm{R}, \mathrm{R}$ square, adjusted $\mathrm{R}$ square, and standard error are reported. In this research, its value is reported equal to 0.013 . It means that the sum of independent variables explains only $1.3 \%$ of the total variance in the dependent variable and the rest of the changes are affected by the variables outside of the model. Value of the estimation standard error which represents prediction power of the regression equation is reported equal to 7.11358 .

Table 5 presents the results of variance analysis. In this table, the source of F-statistic (Fisher Statistic) indicates whether the research regression model is fit or not. In other words, it indicates whether the independent variables are able to properly explain changes of the de-

Table 3. Results of Pearson Correlation Coefficient for the research variables.

\begin{tabular}{|c|c|c|c|c|c|}
\hline Dimensions & (1) & (2) & (3) & (4) & (5) \\
\hline Pleasure & 1 & & & & \\
\hline Arousal & $0.698^{* *}$ & 1 & & & \\
\hline $\begin{array}{c}\text { spent time for } \\
\text { search in the store }\end{array}$ & $0.558^{* *}$ & $0.595^{* *}$ & 1 & & \\
\hline $\begin{array}{l}\text { tendency to } \\
\text { repurchase }\end{array}$ & $0.579^{* *}$ & $0.663^{* *}$ & $0.645^{* *}$ & 1 & \\
\hline $\begin{array}{l}\text { tendency to } \\
\text { recommend } \\
\text { to others }\end{array}$ & $0.551^{* *}$ & $0.626^{* *}$ & $0.578^{* *}$ & $0.674^{* *}$ & 1 \\
\hline presence of music & $-0.106^{*}$ & -0.082 & -0.093 & $-0.136^{* *}$ & $-0.100^{*} \quad 1$ \\
\hline \multirow{2}{*}{\multicolumn{6}{|c|}{$\begin{array}{l}{ }^{*} \text { Correlation is significant at the } 0.05 \text { level ( } 2 \text {-tailed). }{ }^{* *} \text { Correlation is sig } \\
\text { nificant at the } 0.01 \text { level ( } 2 \text {-tailed). } \\
\text { Table } 4 \text {. Summary of the statistics regarding the model fit- } \\
\text { ness. }\end{array}$}} \\
\hline & & & & & \\
\hline \multicolumn{2}{|c|}{$\begin{array}{c}\text { Multiple correlation } \\
\text { coefficient }\end{array}$} & $\mathrm{R}^{2}$ & \multicolumn{2}{|c|}{ Adjusted $\mathrm{R}^{2}$} & $\begin{array}{l}\text { Estimation } \\
\text { standard error }\end{array}$ \\
\hline \multicolumn{2}{|c|}{$0.125^{\mathrm{a}}$} & 0.016 & \multicolumn{2}{|c|}{0.013} & 7.11358 \\
\hline
\end{tabular}

a. Predictors: (Constant), Music 
Table 5. Results of variance analysis.

\begin{tabular}{|c|c|c|c|c|c|c|}
\hline Mode & & Sum of squares & Df & Mean squares & $\mathrm{F}$ & Sig. \\
\hline \multirow{3}{*}{1} & Regression & 348.804 & 1 & 348.804 & & \\
\hline & Residue & 21860.532 & 432 & 50.603 & 6.893 & $0.009^{\mathrm{a}}$ \\
\hline & Total & 22209.336 & 433 & & & \\
\hline
\end{tabular}

a. Predictors: (Constant), Music

pendent variable or not. Based on the results of the below table, $\mathrm{F}$ value is equal to 6.893 and is significant at an error level of smaller than 0.01 .

In Table 6, the results regarding regression coefficients of the independent variable's effect on the research dependent variable has been shown. In this research, the estimated model is:

$$
\text { Consumer behavior }=44.585+(-0.835)(\text { music })
$$

The beta coefficient of -0.125 indicates that change of one standard deviation in variable music causes a standard deviation change of -0.125 in variable consumer behavior.

\section{Discussion}

In today's competitive environment, customer satisfaction and retention as the main focus of customers strategic marketing planning is the key factor to achieve a competitive edge and the prerequisite to win customer satisfaction is fulfillment of all his needs and identification of his wishes, expectations, abilities and limitations in purchase of products. To obtain information on these aspects, determinants of consumers' behavior ought to be properly identified and be used in making marketing decisions. In the present research, we aimed to investigate the effect of music playing in attire stores on consumers' response and behavior. The obtained results from the first and second hypothesis indicated that music playing had no effect on the amount of time spent for search in apparel stores. In regard to the third to fifth hypotheses, there is an inverse correlation $(\mathrm{P}<0.05)$. In other words, there is an inverse association between music playing on the one side, and state of pleasure, tendency to recommendation and tendency to repurchase, on the other side. Finally, the results of hypotheses six to eleven indicated that pleasure and arousal as well as dependent variables "increase of spent time for search in the store", "tendency to repurchase" and "tendency to recommend to others" were directly and highly correlated which was found significant at 0.01 significance level (two-tail). In addition, the obtained results from the regression tables report an adjusted $R^{2}$ of 0.013 , indicating that linear regression of the set of independent variables explains only $1.3 \%$ of the total variance in the dependent variable and the rest is the share of other variables, suggesting slight a effect of
Table 6. Results of regression coefficients effect of the independent variable.

\begin{tabular}{cccccc}
\hline \multirow{2}{*}{ Model } & \multicolumn{2}{c}{$\begin{array}{c}\text { Non-standard } \\
\text { coefficients }\end{array}$} & $\begin{array}{c}\text { Standard } \\
\text { coefficients }\end{array}$ & t-value & Sig. \\
\cline { 2 - 5 } & B & Standard error & Beta & & \\
\hline Constant & 44.585 & 5.215 & & 8.549 & 0.000 \\
Music & -0.835 & 0.318 & -0.125 & -2.625 & 0.009 \\
\hline
\end{tabular}

music on consumer's behavior. In regard to the research main hypothesis, the findings indicate an inverse correlation. In other words, music does not reinforce the tendency to repurchase and the tendency to recommend to others. The results of this research are only consistent with the findings of Kim et al. (2009) who investigated the effects of atmosphere and the website (in terms of music and product presentation) on consumers' emotional and cognitive responses in online purchases, suggesting that music, contrary to predictions of the prior research, has no significant impact on consumers' emotions. Moreover, in addition to difference of the statistical population in this research from those of the prior research which was primarily focused on restaurants, our country's cultural con- text is another factor which might affect the results as well.

\section{REFERENCES}

[1] R. L. Oliver, "When Consumer Loyalty?” Journal of Marketing, Vol. 63, 1999, pp. 33-44. doi: $10.2307 / 1252099$

[2] B. E. Hayes, "The True Test of Loyalty," Quality Progress, Vol. 41, No. 6, 2008, pp. 20-26.

[3] J. E. Cho and H. Hu, "The Effect of Service Quality on Trust and Commitment Varying across Generation," International Journal of Consumer Studies, Vol. 33, No. 4, 2009, pp. 468-476.

doi:10.1111/j.1470-6431.2009.00777.x

[4] Y. M. Tseng, "The Impacts of Relationship Marketing Tactics on Relationship Quality in Service Industry," The Business Review, Vol. 7, No. 2, 2007, pp. 310-314.

[5] T. L. Keiningham, L. Aksoy, B. Cooil and T. W. Andreassen, "Linking Customer Loyalty to Growth," MIT Sloan Management Review, Vol. 49, No. 4, 2008, pp. 50-57.

[6] M. Morrison, S. Gann, C. Dueler and H. Oppewal, "InStore Music and Aroma Influences on Shopper Behavior and Satisfaction," Journal of Business Research, Vol. 64, No. 6, 2010, pp. 1-7.

[7] J. Kim, M. Kim and S. Lennon, "Effects of Web Site Atmospherics on Consumer Responses: Music and Product Presentation," Direct Marketing: An International Journal, Vol. 3 No. 1, 2009, pp. 4-19.

[8] R. E. Milliman, "Using Background Music to Affect the Behavior of Supermarket Shoppers," Journal of Marketing, Vol. 46, 1982, pp. 86-91.doi:10.2307/1251706 
[9] R. E. Milliman, "The Influence of Background Music on the Behavior of Restaurant Patrons," Journal of Consumer Research, Vol. 13, No. 2, 1986, pp. 286-290. doi:10.1086/209068

[10] J. I. Alpert and M. I. Alpert, "Background Music as an Influence in Consumer Mood and Advertising Responses," In: T. K. Srull, Ed., NA-Advances in Consumer Research, Vol. 16, Association for Consumer Research, Provo, 1989, pp. 485-491.

[11] J. Kellaris and R. J. Kent, “An Exploratory Investigation of Responses Elicited by Music Varying in Tempo, Tonality and Texture," Journal of Consumer Psychology, Vol. 2, No. 4, 1994, pp. 381-401. doi:10.1016/S1057-7408(08)80068-X

[12] J. Pine and J. Gilmore, "Welcome to the Experience Economy," Harvard Business Review, Vol. 76, No. 4, 1998, pp. 86-91.

[13] J. Herrington and M. Capella, "Effects of Music in Service Environments: A Field Study," The Journal of Services Marketing, Vol. 10, No. 2, 1996, pp. 26-41. doi:10.1108/08876049610114249

[14] P. C. Smith and R. Curnow, "Arousal Hypothesis and the Effects of Music on Purchasing Behavior," Journal of Applied Psychology, Vol. 50, 1966, pp. 255-260. doi: $10.1037 / \mathrm{h} 0023326$
[15] G. C. Bruner, "Music, Mood, and Marketing," Journal of Marketing, Vol. 54, No. 4, 1990, pp. 94-104. doi: $10.2307 / 1251762$

[16] L. Dube and S. Morin, "Background Music Pleasure and Store Evaluation Intensity Effects and Psychological Mechanisms," Journal of Business Research, Vol. 54, No. 2, 2001, pp. 107-113. doi:10.1016/S0148-2963(99)00092-2

[17] P. Kotler, “Atmospherics as a Marketing Tool,” Journal of Retailing, Vol. 49, No. 4, 1973, pp. 48-64.

[18] J. Baker, M. Levy and D. Grewal, "An Experimental Approach to Making Retail Store Environment Decisions," Journal of Retailing, Vol. 68, No. 4, 1992, pp. 445-460.

[19] F. Sweeney and Wilber, "The Role of Cognitions and Emotions in the Music-Approach-Avoidance Behavior Relationship," The Journal of services Marketing, Vol. 16, No. 1, 2002, pp. 51-69. doi:10.1108/08876040210419415

[20] J. Baker, "The Role of the Environment in Marketing Sciences: The Consumer Perspective," In: J. A. Cepeil, et al., Eds., The Services Challenge: Integrating for Competitive Advantage, AMA, Chicago, 1986, pp. 79-84.

[21] E. Spangenberg, S. Spratt, B. Mann and D. Tracy, "Gender-Congruent Ambient Scent Influences on Approach and Avoidance Behaviors in a Retail Store," Journal of Business Research, Vol. 59, No. 12, 2006, pp. 1281-1287. doi:10.1016/i.jbusres.2006.08.006 